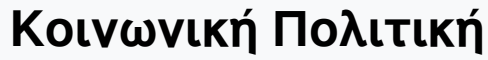

Tóp. 1 (2013)

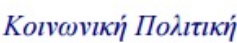

Teixos 1 / A $\pi$ pì̀ı 2013

ПI $\varepsilon \rho \varepsilon \chi \dot{o} \mu \varepsilon v \alpha$

Editorial

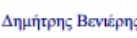

Eı̊์เสá A

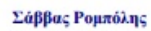

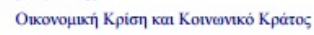

Theodoros Papadopoulos and Antonios Roumpakis

From anti-social policy to generalized insecurity: The Greek crisis meets the

decline of the European Social Model

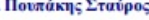

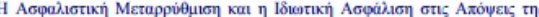

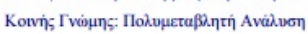

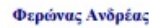

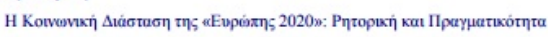

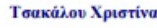

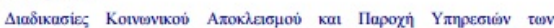

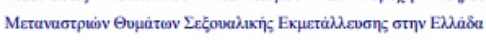

From anti-social policy to generalised insecurity: The Greek crisis meets the decline of the European Social Model

Theo Papadopoulos, Antonios Roumpakis

doi: $\underline{10.12681 / \mathrm{sp} .10551}$

Copyright @ 2016, Theo Papadopoulos, Antonios Roumpakis

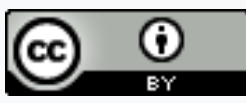

Ađฮıı xpńons Creative Commons Avạopá 4.0.

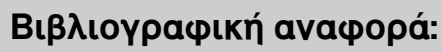

Papadopoulos, T., \& Roumpakis, A. (2017). From anti-social policy to generalised insecurity: The Greek crisis meets the

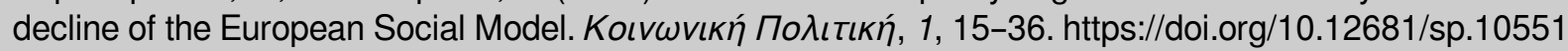




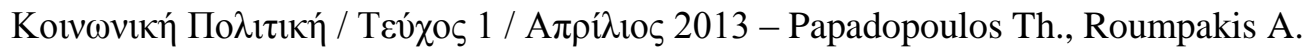

\title{
From anti-social policy to generalised insecurity: The Greek crisis meets the decline of the European Social Model
}

\author{
Theo Papadopoulos ${ }^{1}$ and Antonios Roumpakis ${ }^{2}$
}

\footnotetext{
${ }^{1}$ Department of Social and Policy Sciences, University of Bath, UK (T.Papadopoulos@bath.ac.uk)

${ }^{2}$ Department of Social Policy and Social Work, University of York, UK (@ york.ac.uk)
} 


\section{Introduction}

Our article examines key aspects of the Greek crisis and explores it under the light of the ongoing decline of the European Social Model. It is argued that the austerity measures implemented as conditions for receiving consecutive 'bail-out' loans have had, so far, a very negative impact upon the Greek economy, politics and society. Further, it is argued that labour market reforms underway in Greece and the rest of Southern Europe signal some very worrying developments with respect to the social dimension of European integration. Indeed, especially in the area of collective agreements, when we view these reforms from a European perspective we can identify the rise of wage policy interventionism by the EU; a new process that 'combines European requirements for national wage and labour market policies with the threat of economic sanctions' (Busch et al (2013:8). In turn this signals the intensification of the (neo) liberalisation of the European Social Model and puts under severe doubt the prospects for a more social Europe that will prioritize social objectives and rights over economic freedoms.

The article is structured as follows. The next section deals briefly with the causes of the politico-economic crisis in Greece. It is followed by a discussion of the economic and political effects of the crisis and the impact of austerity measures and reforms. The article continues with a longer section that discusses the impact upon the Greek society and, especially on the familistic model of social reproduction in Greece. In its last part, the article explores the character of labour market reforms in Greece within the context of the ongoing decline of the European Social Model and reflects upon the future prospects for a more social Europe.

\section{The causes of politico-economic crisis in Greece}

Widespread media reports about a looming Greek economic crisis began in October 2009 when the, then, newly elected government of PASOK (traditionally, a centre-left party), led by George Papandreou, was reportedly 'surprised' to discover that Greece's public budget deficit was much higher than previously calculated by the Greek statistical authorities. By 
April 2010, Greece became the first Eurozone member state to formally seek financial assistance from the so-called troika, comprising the International Monetary Fund, the European Union and the European Central Bank. The austerity measures and neo-liberal economic reforms that accompanied the IMF/EU/ECB so-called 'bail out' loans were unprecedented, in their scope, severity, volume and speed. Severe cuts in pensions and wages, extraordinary increases in taxation and dramatic decreases in public spending in most welfare sectors (social security, education, health) accompanied the most extensive de-regulation of industrial relations in Greek history and the abolition of many hard-won socio-economic rights of numerous professions - both in the public and private sectors (see Papadopoulos and Roumpakis 2012). These measures were taken in tandem with an overambitious programme of far-reaching reforms in public administration that includes the future dismissal of thousands of state employees, further privatisation of state enterprises and the selling-off of public property.

Explanations of the causes of the Greek crisis oscillate between those that give emphasis to domestic causes and those that emphasize systemic reasons. For the former, the crisis is mainly attributable to the behaviour of a profligate society that 'consumed beyond its means', and its corrupt governments that run large public debts and budget deficits. For the latter approach, the crisis was the outcome of chronic economic inadequacies and lack of policy options within the Euro, mostly outside the country's influence, with domestic factors acting as triggers rather than as causes of the crisis. In an earlier work (Papadopoulos and Roumpakis, 2012) we drew from both approaches to argue that the eruption of the crisis was the combined result of 'perfect storm' conditions, both domestic and external and placed it in a historical context of repeated state bankruptcies. We also argued that the continuation and deepening of the crisis is a product of the very measures that were taken, supposedly, to alleviate it.

In terms of the domestic causes, the politico-economic regime established after the collapse of dictatorship in 1974 used state resources and public borrowing (see Figure 1) not only as a means to legitimize the young democracy but also to maintain the political reproduction of ruling elites (see Kouvelakis, 2011; Katsimi and Moutos, 2010; Karamesini, 2008) and 
facilitate their enrichment in the context of the semi-peripheral Greek political economy (see Fotopoulos, 1993). Thus, the current crisis in Greece is not purely economic in nature but deeply politico-economic. It marks, among other things, the exhaustion of the politicoeconomic regime that emerged in Greece in the last 35 years characterized by state patronage and clientilism, extensive tax evasion practices (especially of higher earners, businesses and powerful individuals) while privileging specific socio-professional groups via a fragmented and highly unequal social security system (Petmesidou, 1991 and 2011; Venieris, 1997). Further, its corresponding semi-peripheral political economy was 'benefiting' from the functioning of a substantial underground economy, that utilized uninsured and precarious labour, keeping production costs low, while continuing with familistic welfare arrangements that 'externalised' the costs of social reproduction to Greek families (see Papadopoulos and Roumpakis, 2013). These costs continued to remain low, especially since the mid 1990s, due to the extensive use of migrant workers, most of whom where undocumented, especially in the agriculture, construction and domestic/care sectors.

Regarding the systemic factors, one of the key economic consequences of Greece's entry in the Eurozone in 2001 was the dramatic amplification of the already widening asymmetries in productivity and competitiveness between Greece's semi-peripheral economy and those of core EU countries, asymmetries that followed Greece's entry in the EEC in 1981 (see Fotopoulos, 1993). Following the adoption of the Euro, economic growth in the Greek economy was maintained primarily by boosting domestic demand through consumption and to a lesser extent investment in construction and real estate. While the supply of cheap credit from the European Central Bank (ECB) allowed the banking sector to expand rapidly, at the same time the real economy did not yield enough streams of revenue to prevent the accumulation of a high domestic debt while trade deficit worsened (see also Lapavitsas et al, 2010). 
Figure 1 Historical evolution of Public Debt as \% of GDP in Greece, 1960-2012

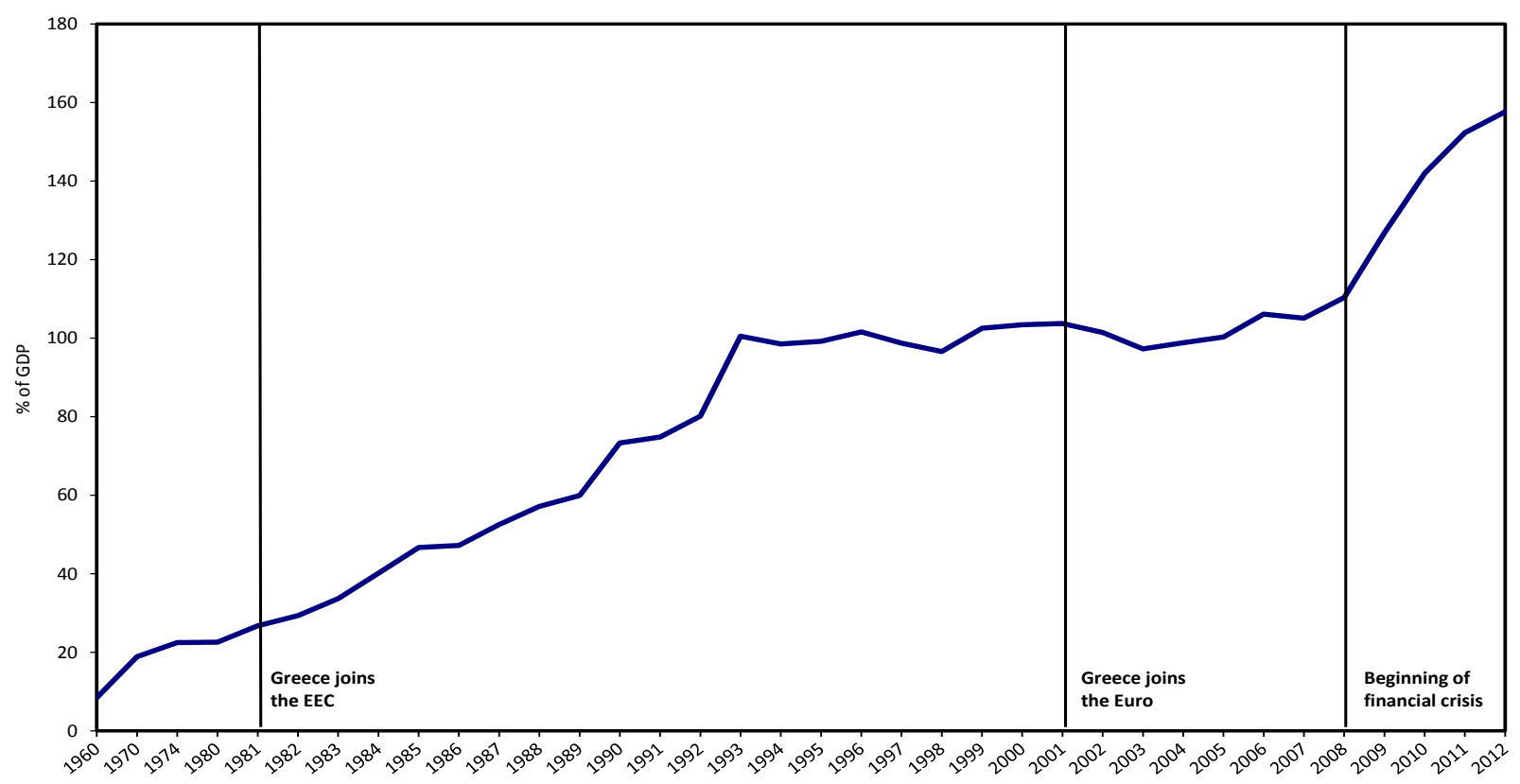

Source: IMF (2011)

Note: Estimated data for 2012

The combination of these systemic factors contributed towards the 'twin deficits' of Greece, on government budget and on the current account balance, which deteriorated dramatically during the period 1999-2008 (IMF, 2011). The end result was that the negative tendencies prior to the entry into Euro (trade deficits, dismantling of the structure of production etc.) were further amplified. The lack of the policy option to issue its own currency meant that, within Euro, Greece's semi-peripheral capitalism stood little chance of balanced endogenous growth (Lapavitsas, 2011; Polychroniou, 2011) similar to other semiperipheral EU economies like Portugal and Ireland (Mansori, 2011).

\section{The politico-economic impact of the crisis and austerity measures}

The combined impact of the crisis and the austerity measures does not allow any room for optimism, economically, socially or politically. Economically, the rapid decline in domestic demand and industrial output was combined with the collapse of bank savings and the 
closure of hundreds of thousands of small-medium (mostly family-owned) businesses. In addition, unemployment has soared and private indebtedness has increased dramatically. The real economy is in a dire state, with GDP continuing to contract year after year with little or no prospect for growth in the short and medium term future. Socially, there is ample evidence of negative developments in respect to social cohesion, poverty and social exclusion, all of which are combined with a dramatic rise in suicides, social unrest and social violence more generally, as well as continuous rise in xenophobia and racism. Politically, nearly 3 years after the eruption of the sovereign debt crisis, the collapse of the two-party system is evident. This collapse was followed by a substantial increase in political uncertainty and political polarisation, marked especially by the spectacular rise of the extreme right. Indeed, this crisis is deeply politico-economic in nature. It signals the end of the politico-economic model adopted since metapolitefsi (the end of military dictatorship in 1974) and the violent restructuring of the Greek social formation and especially its familistic model of social reproduction.

\section{Impact on Greek economy and employment}

The austerity measures adopted under the agreements made with the IMF/EC/ECB included, among other things, relentless taxation and substantial reductions in pensions and wages. In effect, the Greek state has taken billions of Euros out of the (real) Greek economy in order to reduce the budget deficit (and serve the debt) and the results, though predictable, surprised negatively even the most pessimist analysts. By the end of 2011, the Greek GDP had contracted by almost $15 \%$ while the Greek government estimated that by the end of 2012 the Greek GDP would have contracted by a further 7\% (WSJ, 2012). On the other hand, according to a confidential report on the sustainability of Greece's debt (IMF/EC/ECB, 2011; see also Eurobank Research, 2011) the debt was estimated to reach $173 \%$ of GDP in 2012, approximately $€ 373$ billion, from $120 \%$ in 2009 , the year prior to the IMF/EC/ECB 'bailout' loan. In short, while the Greek economy continues to contract, the Greek public debt as \% of GDP continues to rise.

Given that the government shares such pessimistic estimations for the state of the economy in 2012 (WSJ, 2012) one can only question whether there will be any return to positive 
rates of GDP growth in the coming years. So far, the rapid decline in domestic demand, industrial output and bank savings and the collapse of consumer confidence coincide with dramatic increases in unemployment. Indeed, for most Greek citizens of working age, reality in the labour market under the austerity measures marked 'the end of the world' as they knew it. Official unemployment rate more than trippled - from 7.4\% in May 2008 to nearly 25\% in September 2012 (Elstat data reported in FT, 2012) - with women and especially young people hit particularly hard. For the Greek youth, migration emerges as the main exit route to find employment. By the end of 2012, youth unemployment was around $55 \%$ and female youth unemployment stood more than 60\% (Elstat data reported in FT, 2012). In fact, by 2012 Greece was the country with the highest unemployment rate for women (see also Figure 2) and second highest for men and youth, after Spain; both in Southern Europe and the whole of the EU.

Figure 2 Unemployment rates in the GIPS states, 2008 and $2012(\%)$

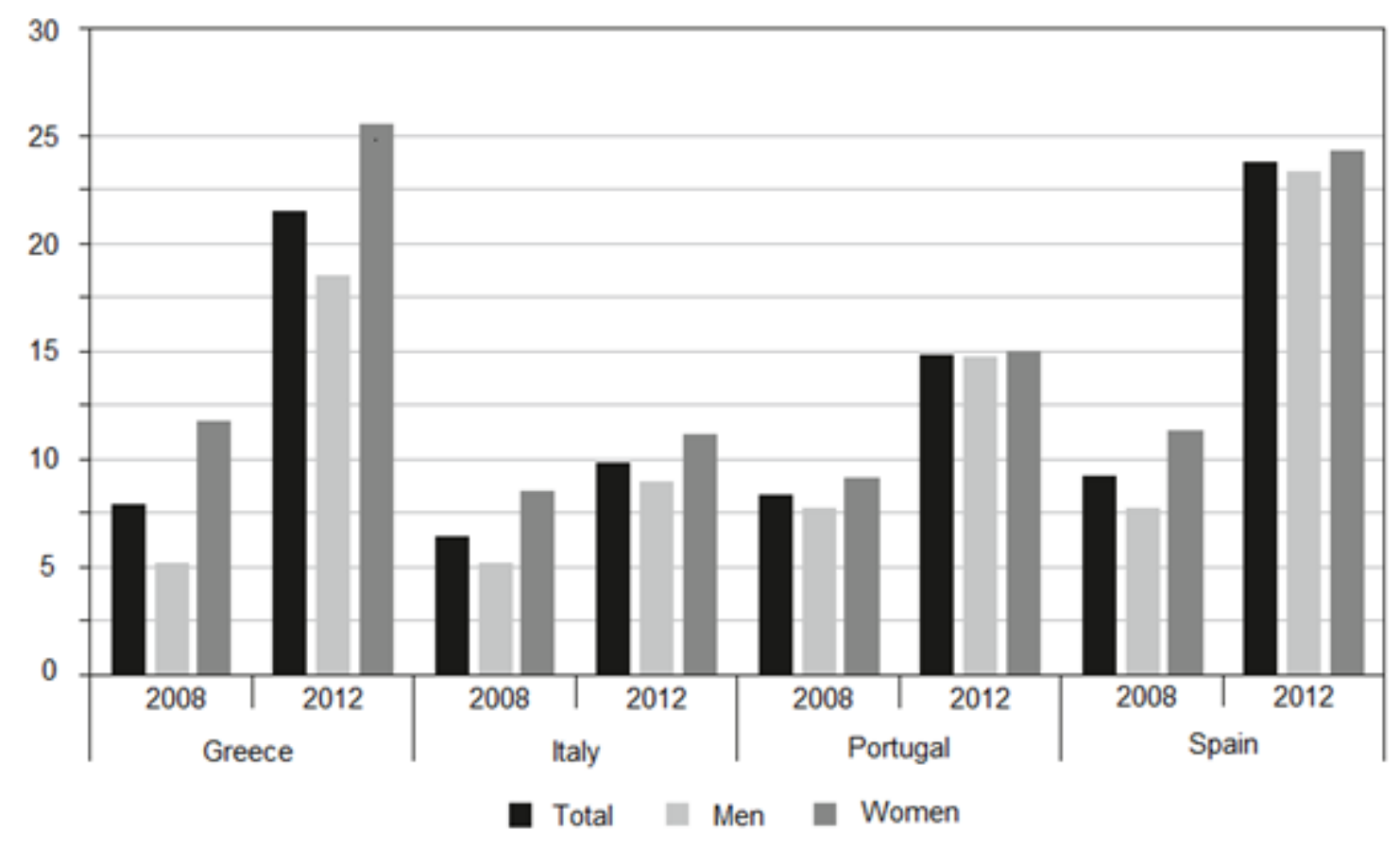

Source: Busch et al (2013) 


\section{Impact on domestic politics}

The economic crisis was accompanied by a political crisis which saw the Papandreou government replaced in early November 2011 by a tri-party 'administrative' government of dubious constitutionality - comprising PASOK, the (conservative) 'New Democracy' party and the far right LAOS party. This government was led by the unelected Lukas Papademos, who was former vice president of the European Central Bank and ex-advisor to G. Papandreou. Papademos' government lasted from November 2011 to May 2012 and, following two general elections in rapid succession (May and June 2012), Papademos was replaced by Antonios Samaras, leader of the New Democracy (ND) party, who managed to form a coalition government comprising his party, the substantially reduced in electoral influence PASOK, and DEMAR, a moderate left-of-centre party. The May 2012 elections saw a major change in the political scene in Greece, with more notable developments, the electoral collapse of PASOK (from $43.92 \%$ of the vote in October 2009 to $12.2 \%$ in June 2012); the catapulting of SYRIZA, the self-described radical left-wing coalition, from $4.6 \%$ of the vote in 2009 to nearly $27 \%$ in June 2012 - narrowly missing becoming the first party in votes - and the unprecedented rise of Golden Dawn, an ultra-right racist party with neo-Nazi tendencies, which from $0.46 \%$ in the May 2009 European elections rose to $6.92 \%$ in June 2012 general elections. In short, the traditional two-party system that dominated Greek politics since the collapse of military dictatorship in 1974 is now confined to history. New political formations are emerging in what is clearly a more polarised political environment, where not only the effectiveness but the very legitimacy of austerity measures is highly contested

\section{Impact of the crisis and austerity measures on society and the model of social reproduction}

Times of crisis are often the best periods to observe key characteristics of social formations and their degree of strength or tenacity. During periods of relative stability, such characteristics can stay obscure or be rendered invisible by political discourses emphasising progress, modernisation or, in the case of Southern Europe, discourses emphasising processes of 'catching-up' with core European economies and welfare regimes. What the 
crisis revealed - and not only for Greece but for the rest of Southern Europe - was the existing (and now widening) fault lines between Southern and Northern/Western European political economies and social formations. We have argued in a previous study (Papadopoulos and Roumpakis, 2012) that the characteristics of South European welfare states were not just endogenous by-products of 'rudimentary' development but, primarily, the results of how their national political economies were integrated in the global and European transnational economies. That is, as semi-peripheral economies that relied on 'external growth strategies' where competitiveness was based on the pursuit of low labourcosts. In turn, this was translated in continuous attempts, on behalf of both employers and the state, to minimize their responsibility for social reproduction. As Bakker and Silvey (2008:3) argue, "the family and the state become important sites where the needs of social reproduction are linked to the need of accumulation and where the state intervenes to offset or offload the high costs of social reproduction onto or away from the family at different moments in different locales". Against this background, the political choice by both the main parties that governed post-dictatorship Greece to avoid introducing a universal system of social protection can be adequately understood. It served well the interests of both employers and the state in minimizing their responsibility for social reproduction in a semiperipheral political economy. The result was the institutionalization of segmented and residual social programmes and welfare policies and reliance on the traditional role that family played in Greek society to provide social protection to its members.

Traditionally, in the familistic model of welfare capitalism in Southern Europe, and especially in Greece, the family played a double role as the main institution for social protection and care of its members and, simultaneously, as a key institution in the reproduction of the particular model of semi-peripheral political economy. The role of the family was not confined to household members but involved utilizing an extensive network of kin that 'provides a mechanism for aggregating and redistributing resources among its members' (Allen et al 2004: 116, see also Ferrera, 1996). In a recent study (Papadopoulos and Roumpakis, 2013a) we argued that this role was interlinked with the capacity of the family to consolidate and mobilise resources as 


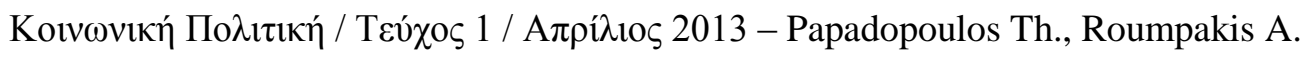

- an owner of property (especially private but also commercial real-estate)

- an employer (usually via family business)

- a member of the clientelistic political system

- a claimant of social security rights (through members able to secure such rights through their participation in the formal labour market and especially though public sector employment).

Further, we distinguished two periods in the social reproduction of the Greek familistic model. The first period, that lasted until the mid-1980s was characterised by strategies of 'maximisation of resources'. Greek families employed strategies of low economic risk that gave strong emphasis on the accumulation of assets and real estate as key resources for their security while avoiding over-exposure to debt and minimising their exposure to the 'money nexus'. The second period, roughly from late 1980s until the eruption of the crisis, was characterised by strategies of high economic risk which utilised market means for the investment and consumption of these resources, strategies that were heavily promoted by the state and banks. The excessive borrowing of households in order to invest in the stock exchange, in the housing market, or in order to improve their living standards via, what proven to be, unsustainable levels of consumption fuelled by cheap credit, resulted in remarkable increases in private debt (see Papadopoulos and Roumpakis, 2009, Lapavitsas, 2011). These practices placed the traditional mode of social reproduction already in a crisis trajectory, years before the eruption of the Greek sovereign crisis.

This point can be supported by analysing the evolution of private debt. Despite the fact that Greek private debt is significantly lower that other Eurozone countries and the UK, private debt and in particular household borrowing boomed a few years before, and especially after, the coming of Euro. In fact it increased faster than the public debt (Lapavitsas et al, 2010) following a trend already set in the 1990s. Since 1994 and up to 2006, the total increase of consumer credit touched upon the astronomical figure of 2,106\% (Papadopoulos and Roumpakis 2009). Sanctioned by the Greek banks, and helped by lower interest rates, this expansion of consumer credit was mainly concentrated on mortgages and on consumer 
loans and left the Greek households exposed to unprecedented levels of debt when the crisis erupted.

Further, even before the EU-IMF bailout, the period 1995-2010 was characterised by the expansion of precarious jobs in the formal labour market, both in the public and private sectors (Karantinos 2006; INE-GSEE 2008). As a precondition for the 'bail-out' loan the government accepted further moves towards the 'flexibilization' of the labour market and strengthening of the rights of employers to 'hire and fire'. Moreover, trade unions would lose their right to refer to the Conciliation and Arbitration Service following disputes with employers over wage increases and collective agreements (on the European dimension of changes in collective agreements see also below). Additionally, as a precondition for the tranche of the 2nd IMF/EU/ECB 'bailout' plan, the Greek government voted to abolish tenure in the public sector. Cornerstones of the Greek labour law are removed fast contributing to the intensification of 'flexibilization' of the Greek labour market. Empirically, this is captured by the significant changes in the number of full and part-time contracts signed in 2010 and 2011. New full-time contracts in 2009 represented $79 \%$ of all contracts. By 2010 they dropped to $66,9 \%$ and by 2011 they were further reduced to 60,4\%. In a reverse fashion, new part-time jobs in 2009 represented 16,7\% of all contracts. By 2010 they increased to 26,1 and by 2011 they reached 30,9\%. New casual jobs also increased from $4,3 \%$ in 2009 to $8,95 \%$ in 2011 (Chalaris, 2012).

The combination of exposure to high levels of private indebtedness and increasing employment insecurity prior to the crisis meant that the familistic model of social reproduction was already quite weak prior to the eruption of the sovereign crisis. The adoption of the austerity measures accelerated what was already a looming crisis in the familistic model of social reproduction and, in fact, resulted in a paradoxical, and very disturbing, development: the social risks, hardships and, ultimately, the responsibility of dealing with the impact of the sovereign debt crisis were transferred almost singlehandedly to the working population, pensioners and their families, both in the public and private sector. While the costs of the sovereign debt crisis are 'familialized', Greek families cannot 
use traditional strategies to protect their members, given that they key pillars of their security (relatively protected employment for at least one member of the family and small ownership) are under attack.

According to statistics of the National Bank of Greece (NBG 2011), the distribution of private debt among household and business debt reached 59.2\% and 60,2\% of the GDP respectively. The same report highlighted serious delays in the payment of mortgages while non-payment of consumer loans has reached 20\%. More recent surveys in the Athens area reported that 6 out of 10 households find it very hard to meet their tax obligations, loans and utility bills while 52\% reported difficulties in meeting even their basic everyday needs (IME-GSEBEE, 2012). Further, according to the latest Eurostat statistics, $31 \%$ of the total population were at risk of poverty or social exclusion at the end of 2011 with the respective figure for children less than 18 at $30.4 \%$, while the children at risk of monetary poverty of parents with low education climbed to 50.2\% (Eurostat, 2013; see also Elstat, 2012).

Apart for a small minority, most Greek families experience a dramatic decrease in their wellbeing and their socio-economic security, as repeated surveys in subjective economic hardship reveal. In 2011 Gallup's ongoing Global Wellbeing Survey reported 60\% of Greeks 'struggling' with their current life while 'the percentage of Greeks who rate[d] their lives so poorly that they are considered 'suffering' more than tripled to $25 \%$ in 2011 , from $7 \%$ in $2007^{\prime}$ (Gallup, 2011a). This was the highest percentage among the Eurozone countries and is expected to increase further. Using questions measuring the Index of Personal Economic Distress (IPED) an epidemiological study conducted by the Athens University Research Institute for Psychiatric Health recorded a nearly $21 \%$ increase in respondents reporting very high economic distress in comparison to 2009 (URIPH, 2011). The same study recorded substantial increases in feelings of melancholy, symptoms of clinical depression, suicidal thoughts and self-reported suicidal attempts. More recent comparative studies on the impact of austerity cuts upon health recorded dramatic rises in suicides as well as incidence of mental health disorders across Europe, especially in Greece and Spain (Coghlan, 2013). According to Violatzis (2011) the total number of suicides 
doubled in the years of the crisis; an unprecedented development for Greece, a country that traditionally recorded one of the lowest suicide rates in the EU.

\section{Change in gender dynamics and lack of public support for families}

Despite the very high female unemployment in Greece many women tried to enter again the labour market after the crisis. Reflecting on this observation Karamessini (2011) mentioned 'It's an attempted defence against the crisis [...] As joblessness rises among men, a growing pool of women are seeking to offset losses in household income [but] most aren't finding work'. This tendency was confirmed by Paul Swaim, a principal OECD labor economist. Although female employment rate in Greece dropped since 2008, female labor force participation rate increased by 2.9 percent (almost 3 times E.U. average), which, as Swaim argued 'shows that Greek women ventured into the labor market in a bid to cushion the impact of the recession on their family's income but often failed to find a job, at least one that is reported to the government' (Swaim, 2011).

Further, those lucky who do find jobs, often find positions inferior to their qualifications while salaries are so low that the prospect for young couples to have more than one child has almost disappeared. At the same time any childbearing plans for childless couples are pushed way back in time (see the extensive report of New York Times, 2011). And more, under conditions of high and rising unemployment, with employment rights severely curtailed and job insecurity rampant, employers can make the most audacious, and often illegal, demands. It has become almost universal practice 'in the private sector [that] if you look for a job and you are of reproductive age the first thing you have to do is give your word of honour that you will not get pregnant' as Pantazi, chair of the Women's Union of Greece, commented in an interview in the Guardian (2012). Against such developments it is reasonable to assume that the already very low fertility rate in Greece (estimated at 1.39 in 2011) will fall even further.

Moreover, it is expected that severe cuts in the public sector, both in expenditures and in terms of personnel, are already having a negative impact upon employment security and it 
appears that this impact is far more severe upon women than men. Karamessini (2011) mentioned that "the state used to represent a guaranteed source of employment for women and had boosted gender equality" with almost $60 \%$ of female university graduates traditionally finding employment in the wider public sector. Further, in a NYT report (2011) it was also mentioned that 'the prospects for female entrepreneurs are also slim as small businesses, which constitute 96 percent of all enterprises in Greece, are closing at a rate of one in four'.

At the same time, a large number of publicly provided services and sectors (e.g. hospitals, schools, universities, welfare services) are facing a double challenge. On the one hand they have to offer their services under serious economic constraints, reduced staff and budgetary cuts - as the state withdraws its funding. On the other hand, it is reasonable to assume that they are facing substantial rises in the demand for accessing their services given that large parts of the middle classes begin withdrawing from private services as their incomes diminish and, further, that the demand on the voluntary and non-governmental sector to fill the gap will intensify (see Eleftherotypia, 2011 and the Guardian, 2012). Indeed marketbased solutions are no longer an option for many families. As Maria Stratigaki, head of the government's General Secretariat for Gender Equality, mentioned 'paying for help with child care' is an expense that fewer and fewer women will be able to afford' (NYT, 2011).

\section{The Greek crisis as part of the crisis of the European Social Model}

Against the evidence presented thus far, it is important to see not only the quantitative but also the qualitative aspects of the austerity measures and reforms and place them in a wider European context. It is evident that the austerity measures and reforms undertaken so far (for a detailed discussion of reforms see Venieris, forthcoming) are firmly within a neoliberal trajectory which not only affects negatively Greek citizens but contributes to the intensification of the (neo)liberalisation of the European Social Model. This dimension was recently explored in a comprehensive report by Busch et al (2013) who explored how austerity measures in Southern Europe threaten the EU's Social Dimension. Having identified six policy objectives of the European Social Model (macroeconomic policy 
aimed at full employment, real wage increase reflecting productivity, social security offering high levels of protection, employee participation rights, strong public sector, priority of social rights over market freedoms incorporated as clause in the EU Treaty) Busch et al gathered ample evidence to demonstrate that, aside the causes of the crisis, the type of austerity measures and their politico-economic effects in Southern Europe are deleterious for the objectives of the European Social Model. They undermine the social dimension of EU's integration process, rendering progressive politics towards a more social Europe increasingly impossible.

For these authors the 'long march' of the liberalization of the ESM began years before the crisis of 2008/9 by means of continuous undermining of employment and social rights, 'labour market reforms, decentralisation of collective bargaining systems, wage moderation, a reduction in relative pension levels, cuts in public health services and privatisation of services of general interest' (p.6). Most of these have taken place in Western and Eastern EU member states whereas in Southern Europe the failure of many attempts of such reforms can be attributed to serious and sustained defence of hard-won rights coming from trade unions and parties of the left. For Busch et al (2013) 'since the global economic crisis of 2008/2009 and austerity policy in the wake of the euro crisis, the political and social balance of power has been changing in Southern Europe' (p.6). This marks a major setback in 'the realisation of a normative concept of a European Social Model - which could already be observed before the crisis' (p.7).

\section{Box 1 Changes in collective agreements systems in Southern Europe}

(already made or planned for the near future)

- legal extension of opening clauses for enterprise level deviations from branch collective agreements (Italy, Portugal, Spain);

- absolute priority of company agreements over all other collective agreements, with simultaneous abolition of the favourability principle (Greece, Spain);

- the possibility for deviating company agreements with non-trade union workers' representations (Greece, Portugal);

- limitation of the validity of collective agreements after expiry (Greece, Spain);

- formal restriction of the general validity of collective agreements (Portugal)

Source: Busch et al (2013:5) 
One of the most worrying developments is the rise of EU's new wage policy interventionism which 'combines European requirements for national wage and labour market policies with the threat of economic sanctions' (Busch et al, 2013:8). It takes place against the background of an explosive increase in unemployment in Southern Europe and is used as a power resource for legitimising and implementing structural reforms against collective agreement systems that traditionally offered high levels of coverage among the working population (see Box 1). In particular, under the rhetorical guise of improving the quality of economic coordination in the EU, and using the new Euro Plus Pact as a legal framework, wage policy is now explicitly considered as part of European economic governance and in fact 'the most important adjustment variable for promoting competitiveness' (Busch et al, 2013:8). Not only this goes against the fundamental principle of the 'voluntary' nature of the contract between labour and capital in a labour market but violates the EU Treaty itself which explicitly rules out any EU competence in respect to wage policies (Article 153, paragraph 5). If we combine this negative development with the prioritisation of economic 'freedoms' over collective labour rights that is being witnessed over the last decade in key rulings of the European Court of Justice in cases pertaining cross-border industrial relations (see Papadopoulos and Roumpakis, 2013b), we can only conclude that the future of national collective agreements - probably the most fundamental institutionalised power resource for European workers - is now seriously under question across Europe. Calling it a new form of authoritarian neoliberalism, Busch et al (2013) lament the developments in Southern Europe where 'in a short time historically developed institutions have been destroyed and reshaped in accordance with a neoliberal master plan under the auspices of the Troika' (p.13).

\section{Conclusion: Anti-social policy in Greece amidst the rise of authoritarian neoliberalism in Europe}

If we adopt the classic normative view of social policy - originally developed by authors like Otto von Zwiedineck-Siidenhorst to describe sets of policies that place the cohesion of society at their core (Cahnman and Schmitt 1979: 51) - then the sum of the austerity measures and reforms adopted by successive Greek governments can be indisputably 
characterised as anti-social policy. With large numbers of households and family business indebted, record high unemployment and poverty rates, and successive closure of hundreds of thousands of small businesses, middle classes in Greece are facing a free fall in their incomes and an unprecedented assault in their socio-economic security. The strategy of internal devaluation promoted by the troika and adopted by the Greek governments, the cuts in salaries, benefits and pension entitlements, and the imposition of a highly regressive tax system, continues to place Greece in a downward spiral of a prolonged recession from which no end is in sight. At the end 2012 the Debt to GDP ratio exceeded 172\% of GDP, from $120 \%$ in 2009 , the year prior to the 'bailout loan' agreement. Moreover, at the end of the year of writing this article (2013), Greek GDP is expected to shrink by a further $4.5 \%$, bringing the total contraction of GDP to 25\%, since 2008 (Elstat, 2013).

Out of the ruins of the traditional familistic mode of social reproduction, undermined by more than a decade of indebtedness and almost 3 years of relentless austerity, a political economy of generalised insecurity emerges. Although nearly all social risks are 'familialized', access to resources for social protection is severely restricted for large number of Greek families. The electoral collapse of the established political parties that supported the austerity measures, the rise of political polarisation, xenophobia and racism, the rise of poverty and social dislocation, the dissolution of social cohesion and the reaffirmation of defensive nationalism against what is perceived as a massive attack on national sovereignty are only a few of the socio-political outcomes of the crisis and the anti-social policies currently implemented. Combined with massive unemployment and underemployment, increases in employment insecurity, the removal of hard-won socioeconomic rights, and continuous attacks on incomes and assets, they create a nightmare scenario for socio-political stability amidst continuing economic decline. Indeed, the Greek social formation faces its biggest challenge since WWII. As long as the measures adopted in Greece, and the rest of the Southern Europe, continue their catastrophic impact upon the economy, politics and society there is little hope that the current trajectory of integration in a market-driven federalist EU will change. Under such conditions, it is perhaps now, more than ever in the post-war European history, that a new path is desperately needed to revive 


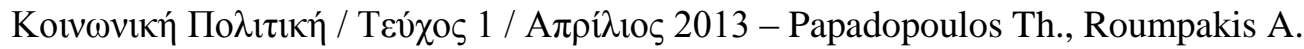

not only the Southern European economies and societies but the European Social Model itself, placing it firmly at the centre of European integration. 


\section{References}

Allen J, Barlow J, Leal J, Maloutas T. and L Padovani L. (2004) Housing and welfare in Southern Europe, Oxford: Blackwell.

Bakker I. and Silvey R. (eds.) (2008) Beyond States and Markets: The Challenges of Social Reproduction, London: Routledge.

Busch K., Hermann C., Hinrichs K., Schulten T. (2013) Euro Crisis, Austerity Policy and the European Social Model: How Crisis Policies in Southern Europe Threaten the EU's Social Dimension, February 2013, Berlin: Friedrich-Ebert-Stiftung.

Cahnman, W. J., \& Schmitt, C. M. (1979) 'The Concept of Social Policy (Sozialpolitik)', Journal of Social Policy, Vol. 8, No 1: pp 47-59.

Chalaris M. (2012), Statements reported in the article 'Explosion in Flexible Employment Arrangements' in $\mathrm{Ta} \mathrm{Nea}$, published 8 April 2012, accessed 8 October 2102 from: http://www.tanea.gr/oikonomia/article/?aid=4703847 [in Greek].

Elstat (2012), Household income and living conditions research in 2011, Athens: Greek Statistical Bureau [in Greek].

Eurobank Research (2011) Greece Macro Monitor - Latest Macro \& Market Developments, 24 October, Athens: Eurobank.

Eurostat (2013), At Risk of Poverty or Social Exclusion in the EU27, News Release No 28, Luxembourg: Eurostat.

Ferrera M. (1996) 'The 'Southern Model' of Welfare in Social Europe', Journal of European Social Policy, Vol. 6, No. 1, pp. 17-37.

Fotopoulos, T. (1993) The Neo-Liberal Consensus and the Crisis of the Growth Economy, Athens: Gordios [in Greek]

FT - Financial Times (2012), 'Greek Unemployment Rises to $24.4 \%$ ' by Kerin Hope, published 6 September 2012, accessed 8 October 2102 from: http://www.ft.com/cms/s/0/4ac82614-f831-11e1-bec8-00144feabdc0.html.

Gallup (2011a) 'In Greece, "Suffering" Up Sharply to 25\% - Greeks Expect Their Lives in Five Years to be Worse than they are Today', published 25 September 2011, accessed 8 October 2102 from: http://www.gallup.com/poll/149675/Greece-Suffering-Sharply.aspx 
Gallup (2011b) 'Greece's Government Faces Deficit in Public Trust', published 4 November 2011, accessed 8 October 2102 from: http://www.gallup.com/poll/150578/Greece-Government-Faces-Deficit-PublicTrust.aspx

Guardian, The (2012) 'Greek Crisis Hits Women Especially Hard', by Lizzy Davies, published 19 June 2012, accessed 8 October 2102 from: http://www.guardian.co.uk/world/greek-election-blog-2012/2012/jun/15/greek-crisiswomen-especially-hard

IME-GSEBEE (2012), Income and Household Expenditure Survey Report, 11 January 2012, Athens: IME-GSEBEE, [in Greek].

IMF (2011) World Economic Outlook Database, Washington: IMF.

IMF/EU/ECB (2011) Strictly Confidential Report - Greece: Debt Sustainability Analysis, October 21, accessed 8 October 2102 from: http://www.linkiesta.it/sites/default/files/uploads/articolo/troika.pdf

INE-GSEE (2008) The Greek economy and employment, Annual study, Athens: INE-GSEE [in Greek].

Karamessini M. (2011) Statement reported in the article 'The Female Factor - Greek Women Try to Soften the Blow of Austerity' by Niki Kitsantonis, in the New York Times, published 6 June 2011, accessed 8 October 2102 from: http://www.nytimes.com/2011/06/07/world/europe/07ihtgreece07.html?pagewanted=all\&_r=0

Karamessini, M. (2008) 'Continuity and Change in the Southern European Social Model', International Labour Review, Vol.147, No 1, pp.43-70.

Karantinos, Dimitris. (2006) 'Report on Greece', European Employment Observatory Contribution to the EEO Autumn Review 2006 'Flexicurity', Athens: National Centre of Social Research.

Katsimi and Moutos (2010) 'EMU and the Greek Crisis: The Political-Economy Perspective', European Journal of Political Economy, Vol.26, No 4, pp.568-576.

Kouvelakis S. (2011) 'The Greek Cauldron', New Left Review, No 72, NovemberDecember, pp.17-32. 


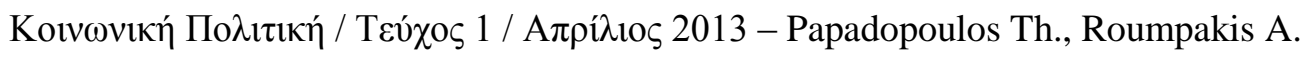

Lapavitsas C. (2011), 'Euro Exit Strategy Crucial for Greeks', in The Guardian, published 21 June 2011, accessed 8 October 2102 from: http://www.guardian.co.uk/commentisfree/2011/jun/21/greek-exit-strategy-bailout$\underline{\text { default }}$

Lapavitsas, C., Kaltenbrunner A., Lambrinidis G., Lindo D., Meadway J., Michell J., Painceira J.P., Pires E., Powell J., Stenfors A., Teles N. (2010) The Eurozone Between Austerity and Default, RMF occasional report.

Mansori K. (2011) 'Why Greece, Spain, and Ireland Aren't to Blame for Europe's Woes', The New Republic, published 11 October 2011, accessed 8 October 2102 from: http://www.tnr.com/article/economy/95989/eurozone-crisis-debt-dont-blame-greece

National Bank of Greece (2011), Bulletin of Conjectural Indicators, Number 138, JulyAugust 2011, [in Greek].

Coghlan A. (2013) Costs of Cuts: Austerity's Toxic Genetic Legacy, New Scientist, published 10 April 2013, accessed 11 April 2103 from: http://www.newscientist.com/article/mg21829122.800-the-hidden-costs-ofausterity.html

NYT -New York Times (2011) 'The Female Factor - Greek Women Try to Soften the Blow of Austerity’ by Niki Kitsantonis, published 6 June 2011, accessed 8 October 2102 from: http://www.nytimes.com/2011/06/07/world/europe/07ihtgreece07.html?pagewanted=all\&_r=0

Papadopoulos, T. and Roumpakis, A. (2012) 'The Greek Welfare State in the Age of Austerity', Social Policy Review, Issue 24, pp. 205-230.

Papadopoulos,T. and Roumpakis A. (2009) 'Familistic Welfare Capitalism in Crisis: The Case of Greece', ERI working paper series, WP-09-14.

Papadopoulos,T. and Roumpakis A. (2013a), 'Familistic Welfare Capitalism in Greece: Crisis of Social Reproduction and Ant-Social Policy' in Zabarloukou S. and Kousi M. (eds.) Social Aspects of the Crisis in Greece, Athens: Pedio [in Greek].

Papadopoulos, T. and Roumpakis, A., (2013b - forthcoming) 'The Meta-regulation of European Industrial Relations: Power Shifts, Institutional dynamics and the Emergence 
of Regulatory Competition Among EU Member States', International Labour Review, Vol.152, No 3, Geneva: ILO.

Petmesidou M. (2011) 'What Future for the Middle Classes and "Inclusive Solidarity" in South Europe?', Global Social Policy, Vol. 11 No. 2-3, pp.225-227.

Petmesidou M. (1991) 'Statism, Social Policy and the Middle Classes in Greece', Journal of European Social Policy, Vol. 1 No. 1. pp. 31-48.

Polychroniou C.J. (2011), An Unblinking Glance at a National Catastrophe and the Potential Dissolution of the Eurozone, University of Massachusetts, Amherst: Political Economy Research Institute, Research Brief, September .

Swaim P. (2011) Statements reported in the article 'The Female Factor - Greek Women Try to Soften the Blow of Austerity' by Niki Kitsantonis, in the New York Times, published 6 June 2011, accessed 8 October 2102 from: http://www.nytimes.com/2011/06/07/world/europe/07ihtgreece07.html?pagewanted=all\&_r=0

URIPH (2011) Results of National Survey of Psychiatric Health reported in the article 'They Are Thinking to Pay for the Crisis with their Lives' by Maria Dede, in Eleftherotypia, published 5 October 2011, accessed 8 October 2102 from: http://www.enet.gr/?i=news.el.ellada\&id=315386 [in Greek].

Venieris D. (1997) 'Dimensions of Social Policy in Greece' in Rhodes M. (ed.), Southern European Welfare States: Between Crisis and Reform, London: Frank Cass and Co.

Venieris D. (forthcoming) 'Economic Crisis and Social Policy Deregulation: The New 'Greece Minor Disaster' 2010-11', Greek Review of Social Sciences, Athens: National Centre of Social Research, [in Greek]

Violantzis A. (2011) 'Surge in economic suicides', Interview in TVXS, published 22

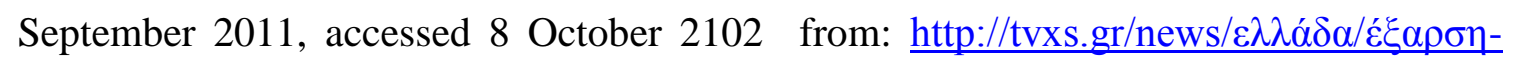

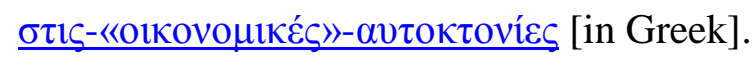

WSJ - Wall Street Journal (2012) 'Greek Economy to Shrink More Than Expected Next Year' by Stelios Bouras, published 30 September 2012, accessed 8 October 2102 from: http://online.wsj.com/article/SB10000872396390443862604578028802369884088.html 